\title{
Tree response to bark harvest: the case of a medicinal species, Garcinia lucida, as source of raw materials for plant-based drug development
}

\author{
Nicole Marie GUEDJE (1*), Nicodeme TCHAMOU (2), Jean LEJOLY (3) \\ 1. Department of Pharmacognosy and Pharmaceutical Chemistry, Faculty of Medicine and Biomedical Sciences, \\ University of Yaounde 1; manigue@hotmail.com ; +237 676075355 \\ 2. USAID Regional Office, Accra - Ghana; ntchamou@usaid.gov; +233 244313549 \\ 3. Laboratoire de Botanique Systématique et de Phytosociologie, CP 169, Université Libre de Bruxelles" / GI Agro \\ ONG, Ibi, Kinshasa, RD Congo ; jean!@ibi-village-cd / lejoly@ulb.ac.be ; +243 816566781 / +32 479990362 \\ * Corresponding author: Nicole Marie GUEDJE, PO Box: 25645 Messa - Yaounde, Cameroon \\ E-mail: manigue@hotmail.com ,Phone : + 237699685850 / 676075355
}

Original submitted in on $11^{\text {th }}$ January 2016. Published online at www.m.elewa.org on $31^{\text {st }}$ March 2016 http://dx.doi.org/10.4314/jab.v99i1.13

\begin{abstract}
Objectives: There is a huge demand for medicinal bark in developing countries and this demand is growing fast due to it high market values. To assess the effects of bark functions and tree capacities to recover from various debarking practices, a two-year experiment was conducted and several local harvest practices were tested on Garcinia lucida.

Methodology and Results: For each practice, 20 healthy trees were selected and harvested. Tree health was monitored every month and the total bark regrowth was calculated using planimetric techniques. In response to bark removal, G. lucida trees produced stilt-roots, sprouts and bark. Re-growth of bark was the most common strategy developed, with mean values ranging from 80 to $100 \%$ of trees. All stumps have developed sprouts, with an average number of 6 shoots per stump. The percentage of bark regrowth varies from 45 to $62 \%$ of the initial surface debarked for small trees and from 24 to $37 \%$ for large trees. A high rate of bark regeneration was found if narrow strips of bark remained on trees, from which bark was hardly removed from wood during harvest, probably characterized physiologically by a downward sap flow due to poor water supply in trees.

Conclusions and application of findings: The study has discussed main findings on the experimental debarking of $G$. Iucida and management implications, which would also apply to other species with the same response to bark stripping as source of raw materials for plant-based drug prospects in developing countries. Bark strip harvesting requires species-specific parameters to make it sustainable, taking into account : (i) the bark regeneration capacity (edge growth), which may allow repeated harvest on the same tree; and (ii) the physiological status (downward sap flow) of the tree at the time of harvest, as decisive factor triggering bark regrowth. Partial bark strip harvesting show good prospects for the implementation of long-term sustainable strip harvesting prescriptions, while sustainable stripping through ring-barking practice is unsuitable. Shoot growth and stilt-root development in G. lucida species allows for other management options than strip harvesting, including coppice management and domestication. However, there are major limitations in using
\end{abstract}


regenerated bark, as the time required to re-attain preharvest bark thickness, as well as the chemical composition due to stress-releasing mechanisms remain unknown.

Key-words: medicinal bark regrowth, harvest practices, plant-based drug prospects, species recovering capacity, sprouting capacity.

\section{INTRODUCTION}

Tropical forests in developing countries have been traditionally exploited for a wide array of natural resources by billions of people for their livelihood. One of these resources is the bark of tree species, most commonly employed for many purposes such as medicines, dyes, food spice, wine flavour, and a range of other uses (Tshisikhawe et al., 2012; Cunningham, 2014a; Senkoro et al., 2014). The global demand for medicinal bark is steadily growing and has caused some valued indigenous plant species, very sensitive to high levels of harvest, to become threatened (Ndoye et al., 2000; 2001; Djaligue, 2007; Tshisikhawe et al., 2012; Cunningham, 2014a,b; Bodeker et al., 2014). Therefore, there is an increasing concern about the management of medicinal bark harvesting (Pandey \& Das, 2013; Baldauf \& dos Santos, 2014; Mariot et al., 2014; van Andel et al., 2015; Pandey, 2015). The term bark refers to all tissues outside the vascular cambium, comprising dead and live tissue (Camefort, 1977; Romero, 2014; Senkoro et al., 2014). The dead tissue (rhytidome) corresponds to the outer layer of bark, functioning as a physical barrier that protects trees against desiccation, fire, insects, herbivores and diseases. The live tissue (phloem) constitutes the inner bark, playing a key role in nutrient transport. In contrast to leaves or fruits that can be replaced after being damaged or harvested, bark are not ephemeral and thus benefit from avoiding or recovering efficiently from removal. Despite these bark fundamental importance to tree survival and growth, issues such as bark responses to damage have been the subject of comparatively

\section{MATERIALS AND METHODS}

Study site: The study was carried out within an area located in the South Cameroonian Atlantic humid forests, near the village Nyangong $\left(2^{\circ} 56.04^{\prime} \mathrm{N}, 10^{\circ} 49.62^{\prime} \mathrm{E}\right)$ in the Bipindi - Lolodorf - Akom II region (Fig. 1). The climate is humid tropical with two rainy and two drier seasons, with a yearly rainfall of about $2000 \mathrm{~mm}$, and few studies, compared to leaves (Romero, 2014; Costa et al., 2015). Valuable efforts have been made to establish good quality assurance and standardization, as well as specific guidelines for good collection practices for medicinal plant parts (WHO, 2004; Kunle et al., 2012; van Damme \& Delvaux, 2012; Pandey \& Das, 2013). Despite these efforts, lack of sufficient knowledge about structure and functional ecology of the bark, as well as sustainable harvest rates and practices remain some of the major challenges to ensure that the necessary raw materials will be readily available for the development, according to WHO recommendations, of local plant-based industries. Few studies have assessed the ability of trees to regenerate bark following harvesting (Cunningham \& Mbenkum 1993; Geldenhuys et al., 2007; Delvaux et al., 2009; Vermeulen et al., 2012; Baldauf \& dos Santos 2014; Ngubeni, 2015) and have clearly demonstrated that this ability to regenerate bark is species-specific. Such large-scale field or case studies on tree responses after bark harvesting are scarce, but essential to define the maximum sustainable harvesting limit for the bark and to ensure the persistence of a species. To design approaches of sustained sourcing of bark as raw materials for plantbased drug prospects, the present investigation aimed at assessing tree response and abilities to recover from various intensities and techniques of debarking. The approach was illustrated on Garcinia lucida Vesque (Clusiaceae) species, one of the most valued wild medicinal resources in South Cameroon (Guedje, 2014).

with an average annual temperature of around $25^{\circ} \mathrm{C}$. Biodiversity in this part of Cameroon ranks among the highest in Africa. The forest cover is still largely intact, but due to human influence, it is alternated with a mosaic of fields, fallow lands, secondary forest and logged-over forest. 


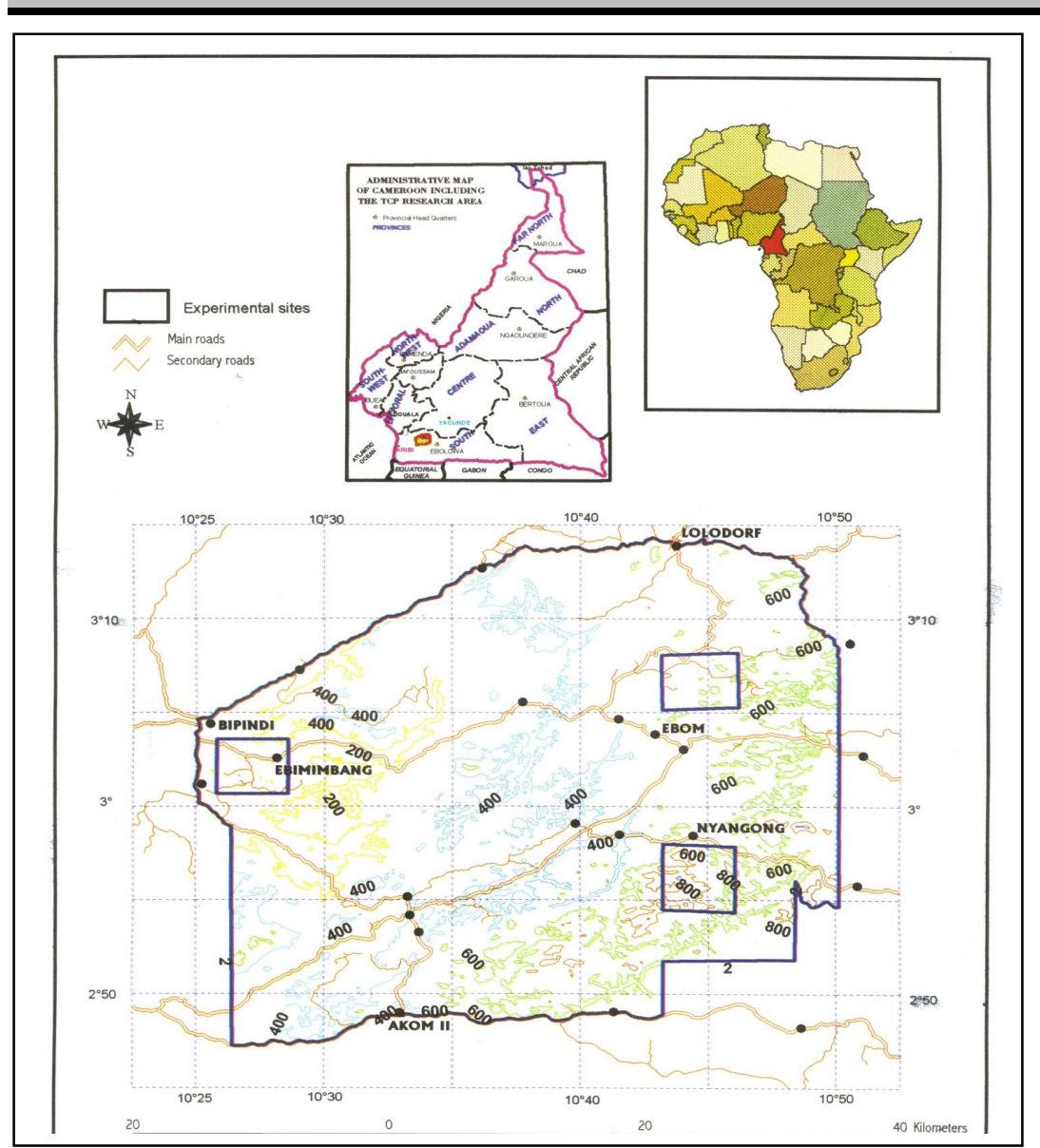

Fig. 1: Location of the Bipindi - Akom II - Lolodorf area in the South Cameroonian Atlantic humid forests.

Study species - Garcinia lucida Vesque (Clusiaceae): G. lucida is a small understory dioecious tree, standing sometimes on stilt roots, reaching $25-30 \mathrm{~cm}$ in diameter at breast height $(\mathrm{DBH})$, with yellow and resinous sap exuded after bark tranche. It grows in high-density stands in hilly moist forests sides. It is well-known in South Cameroun as "Essok" in the Boulou and Ewondo local languages. The bark is one of the most valued and sold non-timber forest products for its multipurpose properties in Cameroon, Gabon and Equatorial Guinea. The bark and the seeds are used as flavour in raphia and palm wine production, as well as in traditional liquor distillery. It is used for medicinal purposes as an antidote against poison or to prevent food poisoning, to cure diarrhoeas, stomach and gynaecological pains, as well as to cure snake bites. It is also believed to possess some aphrodisiac properties and that it could be used to chase away ghosts (van Dijk, 1999; Chikamai et al., 2009). Many active compounds with bioactivities such as antibacterial, antimicrobial, anti-inflammatory, antacids, curare antidote or inhibitory effect, $\beta$-lactamase inhibition have been found in its diverse plant parts (Kamanyi et al., 1990; Nyemba et al., 1990; Fotie et al., 2007; Gangoué-Piéboji et al., 2009; Momo et al., 2011; Lacmata et al., 2012). Bark harvesting has been intensified due to the steadily increasing demand for palm wine and traditional liquor (Ndoye et al., 2001; Djaligue, 2007; Chikamai et al., 2009). Usually, before debarking, a machete is used to test the thickness of the bark and if the bark will be easily detached from the wood. Consequently, many standing trees are covered with scars causing stress and making the tree more susceptible to further damage. Local harvesters apply various bark harvesting practices. This includes, debarking by hammering the stem with a stick (if bark is easily removed from wood) or peeling off the bark with a machete (if bark is thick but hardly removed from wood) one side of reproductive individuals. Very often, though, the bark is removed over almost the entire circumference of the stem, especially when the bark is thick and can be easily detached from the wood, and regardless of whether it is a young or an old mature tree. This practice 
leads to a high mortality of trees (Guedje et al., 2007). A practice, less frequently used, is felling the tree at approximately $1 \mathrm{~m}$ height and harvesting the bark of the felled part.

Experimental design, data collection and analysis: From the above harvesting practices, the following treatments, illustrating the local bark harvesting system, were applied:

(i) Control (C) : no debarking;

(ii) Partial debarking of the stem, with three subtreatments: (a) peeling off pieces of bark with a machete and debarking over $1 / 3$ of the tree circumference at breast height (P 1/3), (b) hammering on the tree with a stick and debarking over $1 / 3$ of the tree circumference at breast height $(\mathbf{H} 1 / 3)$, and (c) hammering with a stick and debarking over $2 / 3$ of the tree circumference at breast height (H 2/3);

(iii) Ring-barking of the stem (R 3/3);

(iv) Felling the tree at approximately $1 \mathrm{~m}$ height above the ground and thereafter harvesting the bark on the felled tree part (F).

For each treatment and each sub-treatment, 20 healthy trees (no scars and previous bark harvest) were selected, marked with numbers, equally distributed in two size classes : [10 - 17[ cm diameter at breast height (DBH) for small trees and $[17-26[\mathrm{~cm}$ DBH for large trees. The sample was restricted to this number of trees and size classes as healthy trees were scarce, and as many $G$. lucida forest stands in the area mostly composed of harvested trees or unharvested trees but covered with many scars. Bark was extracted from $0.3 \mathrm{~m}$ from the ground (or above stilt roots) in a vertical strip up to $1.5 \mathrm{~m}$ stem height. For each treated tree, "bark easiness" to be removed from wood like "cassava peel", or "bark hardness" to be removed from wood were noted. Health parameters (survival, sprouting, bark re-growth, stilt-root development) were monitored every month over a period of two years. Insect holes were noted, new sprouts and shoots around the wound was counted. Re-growth of bark was monitored, and at 6, 12 and 24 months, tracing papers were used to copy the surface area of edge growth on the wound. The total bark area regrowth was calculated using planimetric techniques. Variance (ANOVA) and regression analysis techniques using SPSS have been used to compare the different treatments. At the start of the research, a total of 120 trees were bark stripped. Over the two-year study period, 16 trees $(13.33 \%)$ were illegally stripped again by unknown local community members and struck out from the sample (Table 1).

Table 1: Number of sample trees selected per treatment and number of trees struck out after illegal stripping.

\begin{tabular}{|c|c|c|c|}
\hline Treatment & Initial Sample & Number of treated trees illegally stripped again and struck out \\
\cline { 3 - 4 } & & $\mathbf{N}$ & $\%$ \\
\hline $\mathrm{C}$ & 20 & 4 & 20 \\
\hline $\mathrm{P} 1 / 3$ & 20 & 4 & 20 \\
\hline $\mathrm{H} 1 / 3$ & 20 & 4 & 20 \\
\hline $\mathrm{H} 2 / 3$ & 20 & 3 & 15 \\
\hline $\mathrm{R} 3 / 3$ & 20 & 1 & 5 \\
\hline $\mathrm{F}$ & 20 & 0 & 0 \\
\hline Total & $\mathbf{1 2 0}$ & 16 & 13,33 \\
\hline
\end{tabular}

\section{RESULTS}

Harvest practices impact on tree survival : Damage to and removal of bark has serious effects on plant survival. According to the criteria of bark easiness to be removed from wood like "cassava peel" or bark hardness to be removed, treated trees were distributed as shown in table 2. The proportion of trees where bark was easily removed like "cassava peel" was only $7.5 \%$, while trees that bark was more or less easily removed counted for $51.25 \%$, and trees where bark was hardly removed counted for $41.25 \%$. During the experiment, it was observed that the yellow and resinous sap exudates were abundantly produced along the sides of wounds, regardless of the harvest practices applied. It was also observed that, when bark was easily removed from wood like "cassava peel", trees were entirely stripped of its protective and conducting bark tissues, leading consequently to "cleanstripped" trees. On the contrary, when bark was hardly or very hardly removed from wood, narrow strips of bark tissues always remained on stem wood, together with more yellow and resinous sap exudates produced. When trees were also peeling off with machete, narrow strips of bark tissues always remained on stem wood. During the monitoring of treated trees, it was observed that, trees where bark was easily removed like "cassava peel" have 
undergone rapid and severe dehydration after stripping than those that bark was hardly removed, resulting in the exhibition of external signs of tree die-back six months later after stripping (Fig. 2). The six months' time interval seems to be the time spans needed by trees to overcome the internal stress that may compromise trees fitness and survival. For ring-barked trees, the percentage of mortality increased over time, which a peak between 12 and 15 months. For other treatments, the percent of mortality has remained more or less constant after the first six months.

Table 2: Distribution of G. lucida trees per bark removal easiness categories after stripping.

\begin{tabular}{l|l|c|c|c|c|c|c}
\hline & & \multicolumn{6}{|c}{ Number of treated trees } \\
\hline & & P 1/3 & H 1/3 & H 2/3 & R 3/3 & \multicolumn{3}{|c}{ Total } \\
\cline { 5 - 8 } & & & & & & N & $\%$ \\
\hline Bark removal easiness & Very easy & 3 & 1 & 1 & 1 & 6 & 7.5 \\
category & More or less easy & 11 & 13 & 8 & 9 & 41 & 51.25 \\
& Very difficult & 6 & 6 & 11 & 10 & 33 & 41.25 \\
& Total & 20 & 20 & 20 & 20 & 80 & 100 \\
\hline
\end{tabular}

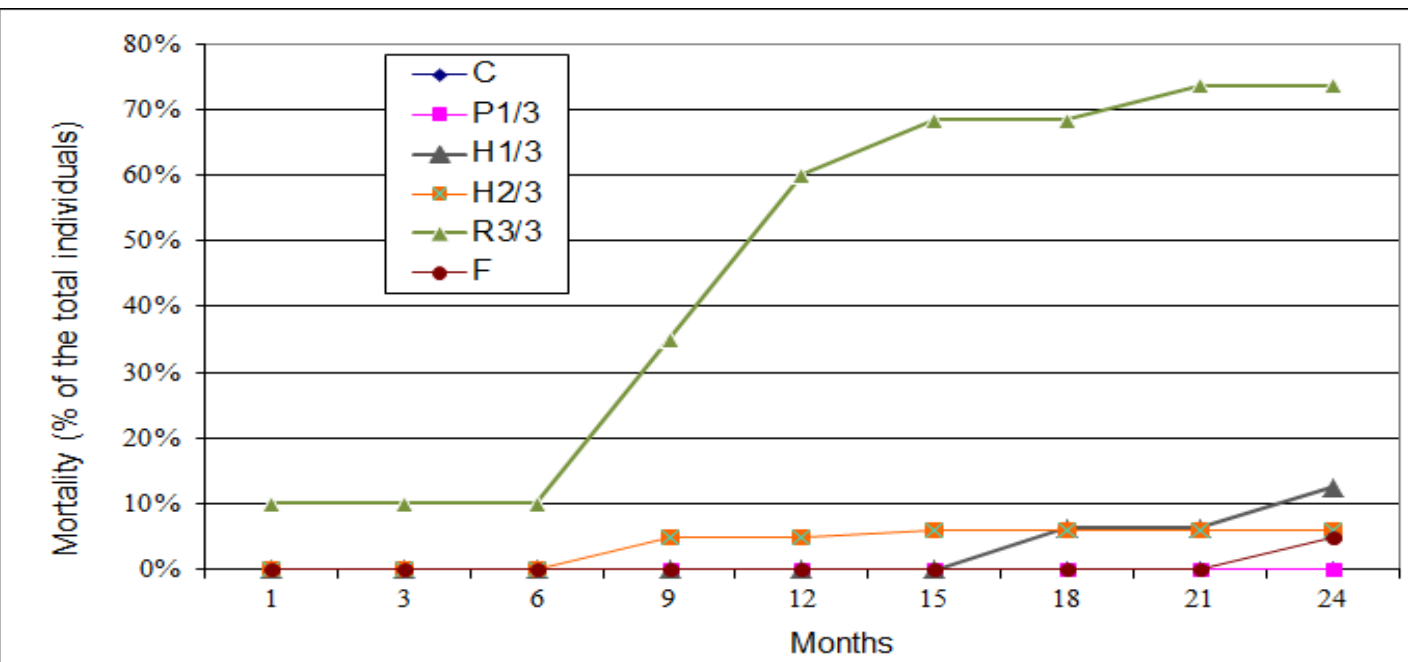

Fig. 2: Characterization of stages of tree fitness and survival in G. lucida over 2 years following bark harvesting, for all size classes. $\mathrm{N}=20$ for each treatment; $\mathrm{P} 1 / 3=$ peeling with a machete and debarking over $1 / 3$ of the circumference, $\mathrm{H} 1 / 3=$ hammering on tree and debarking over $1 / 3$ of the circumference, $\mathrm{H} 2 / 3=$ hammering on tree and debarking over $2 / 3$ of the circumference, $\mathrm{R} 3 / 3=$ Ring-barking tree by peeling with a machete or hammering on tree.

The survival of treated trees was highly influenced by harvesting treatments. Ring-barking of stem was the most destructive, leading to $0 \%$ of surviving large trees, compared to $50 \%$ survival probability for small trees (Fig. 3). In contrast, trees were remarkably tolerant to partial debarking practice, especially in trees peeled with a machete $P 1 / 3$ (100\% surviving trees) compared to trees debarked by hammering with a stick. Concerning felling tree practice, tree survival probability was $100 \%$ for small trees and $90 \%$ for large trees. Although survival probabilities of small ring-barked trees was significantly lower $(p<0.001)$ than those partially debarked, as well as those felled at $1 \mathrm{~m}$ height above the ground and the control, no significant difference was recorded between size-classes in overall practices (variance analysis with LSD at $5 \%$ ), suggesting that tree survival is very sensitive to harvest intensity and practice, regardless of whether it is a young or mature tree. 


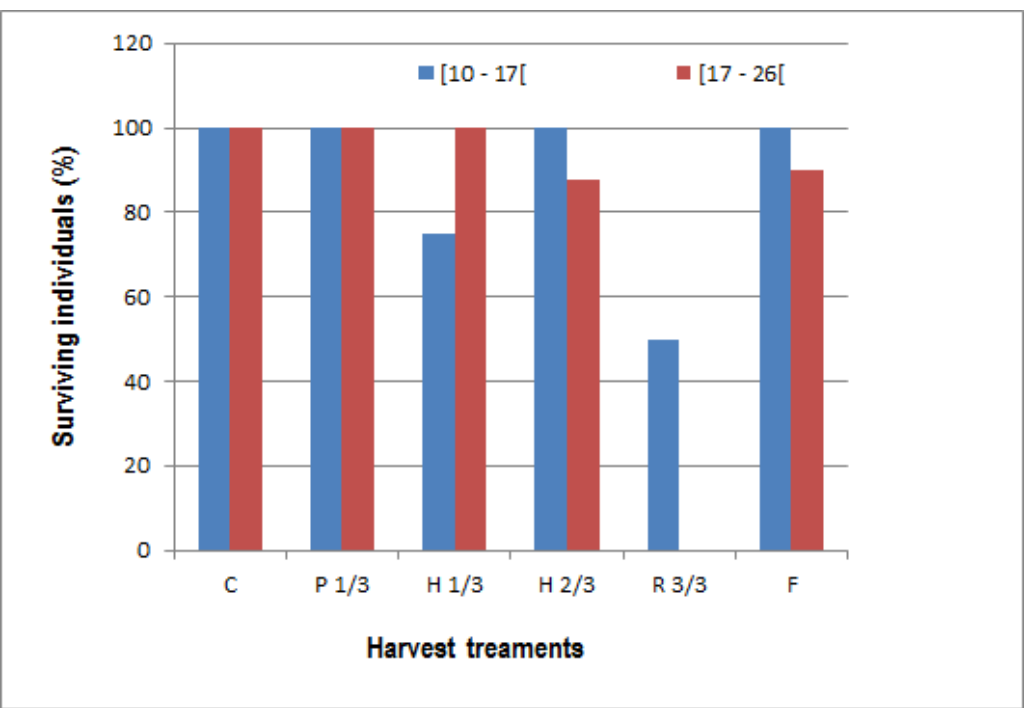

Fig. 3: Comparison of tree survival rate between the harvest treatments for small and large trees 24 months after treatment. $\mathrm{P} 1 / 3=$ peeling with a machete and debarking over $1 / 3$ of the circumference, $\mathrm{H} 1 / 3=$ hammering on tree and debarking over $1 / 3$ of the circumference, $\mathrm{H} 2 / 3=$ hammering on tree and debarking over $2 / 3$ of the circumference, $\mathrm{R} 3 / 3=$ Ring-barking tree by peeling with a machete or hammering on tree.

Tree response capacities after debarking: Three types of plant tissue development in response to bark removal were recorded on surviving trees (Fig. 4): stilt-roots, sprouts and bark. Re-growth of bark was the most common strategy developed, with mean values over $90 \%$ of trees partially debarked. The recruitment of new stilt- roots from the extreme treatments occurred most frequently in the remained $50 \%$ sample of small trees ring-barked and in the $\mathrm{H} 2 / 3$ debarked trees $(33 \%)$, while only $6 \%$ and $7 \%$ of trees have developed stilt-roots in $\mathrm{P}$ $1 / 3$ and $H 1 / 3$ respectively.

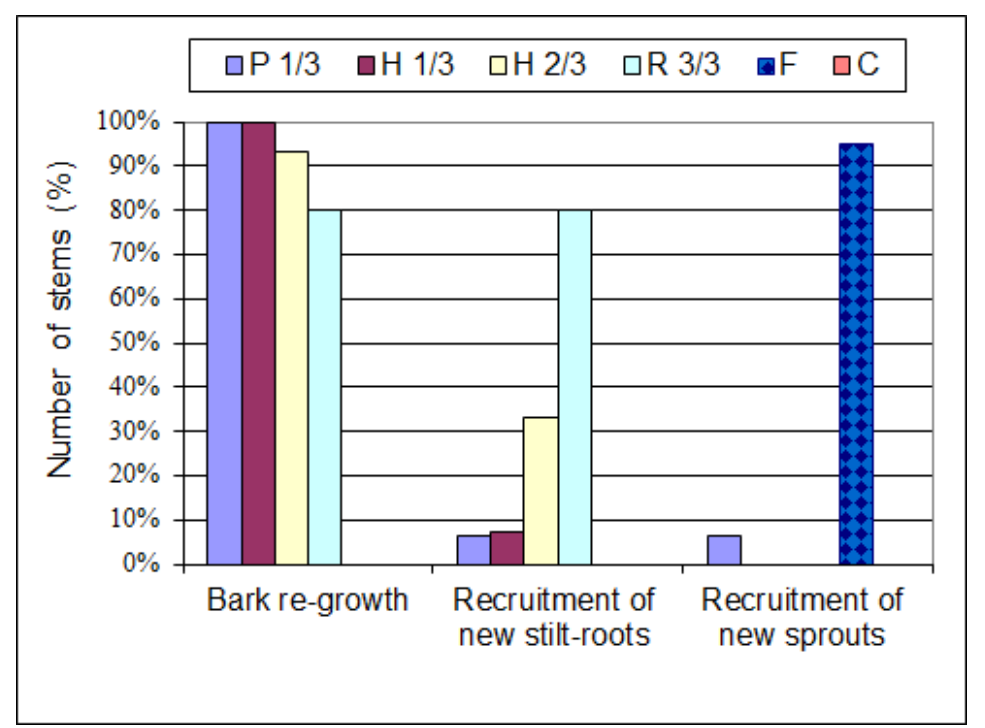

Fig. 4: Frequency of the three types of response to bark stripping in Garcinia lucida, for surviving trees 24 months after treatment $(n=86)$. C $=$ Control $(n=16), P 1 / 3=$ Peeling with a machete and debarking over $1 / 3$ of the circumference $(n=16), H 1 / 3$ $=$ Hammering on tree and debarking over $1 / 3$ of the circumference $(n=14), H 2 / 3=$ Hammering on tree and debarking over $2 / 3$ of the circumference $(n=16), R 3 / 3=$ Ring-barking tree by peeling with a machete or hammering on tree $(n=5), F=$ Felling the tree at $1 m$ height $(n=19)$. 


\section{Guedje et al. J. Appl. Biosci. 2016 Tree response to bark harvest: the case of a medicinal species, Garcinia lucida, as source of raw materials for plant-based drug development}

The development of new sprouts or shoots around the wound was observed only for a few trees in the $P 1 / 3$ treatment ( $6 \%$ of trees), with a mean of only one or two shoots per tree. Comparatively, $95 \%$ of felled trees have developed shoots, with a mean number of shoots varying from 0 to 12 per stump (Fig. 5) and an average number of 6 new shoots per stump. After 12 months, the length of shoots varied between 1 and $65 \mathrm{~cm}$, with an average of $18.3 \mathrm{~cm}$ and an annual growth rate of $14.6 \mathrm{~cm}$.

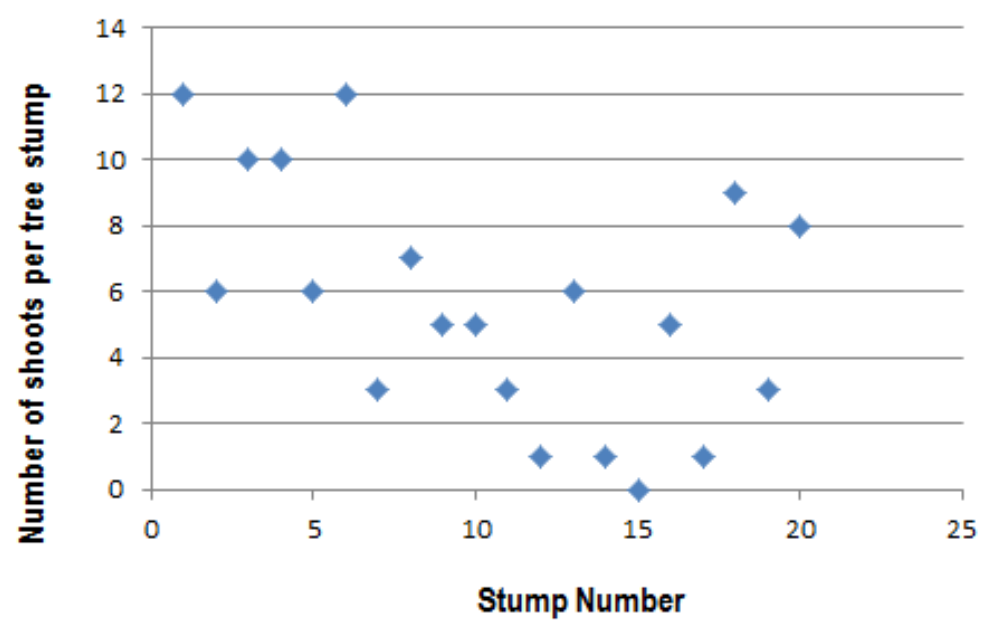

Fig. 5: Vegetative growth of $G$. lucida stumps in response to felling trees at $1 \mathrm{~m}$ height, 12 months after treatment.

Bark regeneration patterns: Bark-regrowth occurred on trees three months later after stripping in overall treatments, with a peak of the maximum number of trees exhibiting the process observed between 9 and 12 months; and after 12 months, a decline, due to the number of trees die-back and struck out after illegal stripping (Fig. 6).

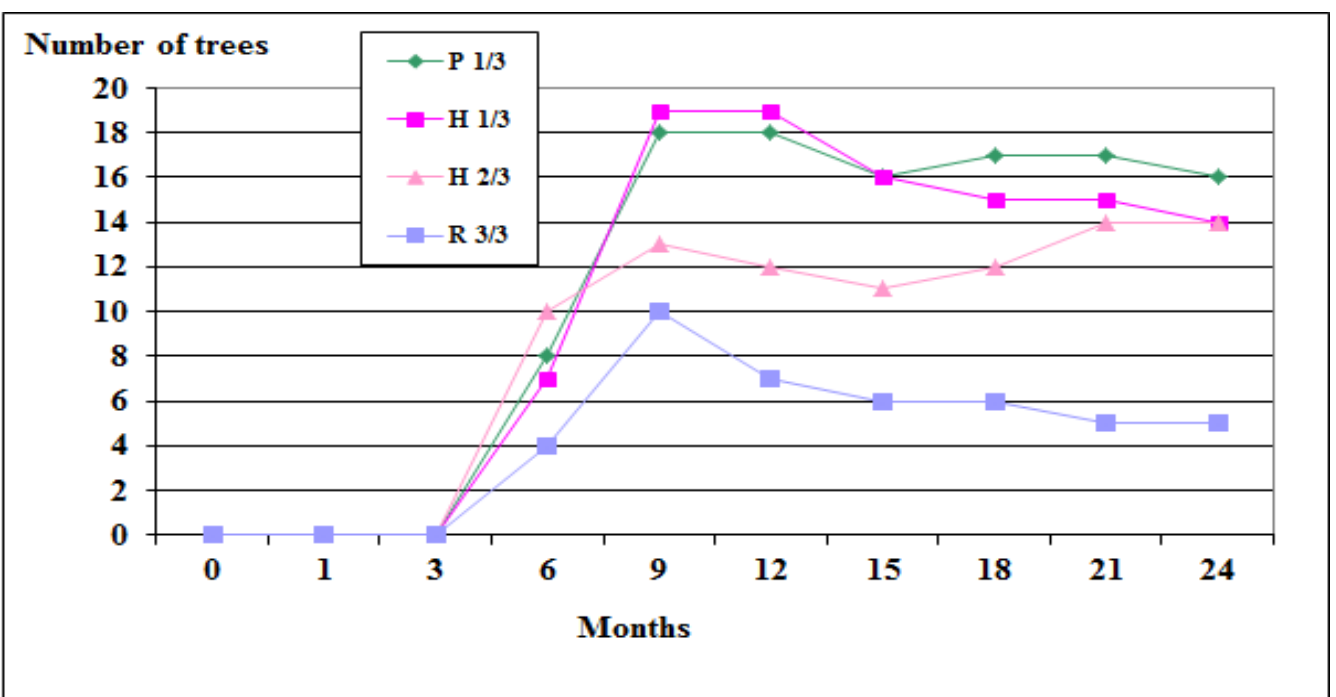

Fig. 6: Characterization of bark-regrowth process in G. lucida over 2 years following bark stripping for all size classes. $P 1 / 3=$ Peeling with a machete and debarking over $1 / 3$ of the circumference $(n=16), H 1 / 3=$ Hammering on tree and debarking over $1 / 3$ of the circumference $(n=14), H 2 / 3=$ Hammering on tree and debarking over $2 / 3$ of the circumference $(n=16), R 3 / 3=$ Ringbarking tree by peeling with a machete or hammering on tree $(n=5)$. 
For each treatment, the average percentage of re-growth area is presented in Fig. 7. For small trees an average comprised between 30 and $50 \%$ of the initial surface debarked was covered by regrowth for the different treatments, compared to 14 and $28 \%$ for large trees, six months after treatment. Bark re-growth started from the sides of wounds toward the center, regardless of the harvest practices applied. After two years, the percentage covered varied from 45 to $62 \%$ for small size trees and from 24 to $37 \%$ for large size trees, indicating that bark regeneration was faster in younger trees. Amongst all these trees, five ( $9 \%$ of trees) have recovered more than $90 \%$ of the surface initially debarked, while 31 trees (58.5\% of trees) have recovered less than $50 \%$ of the total surface debarked.

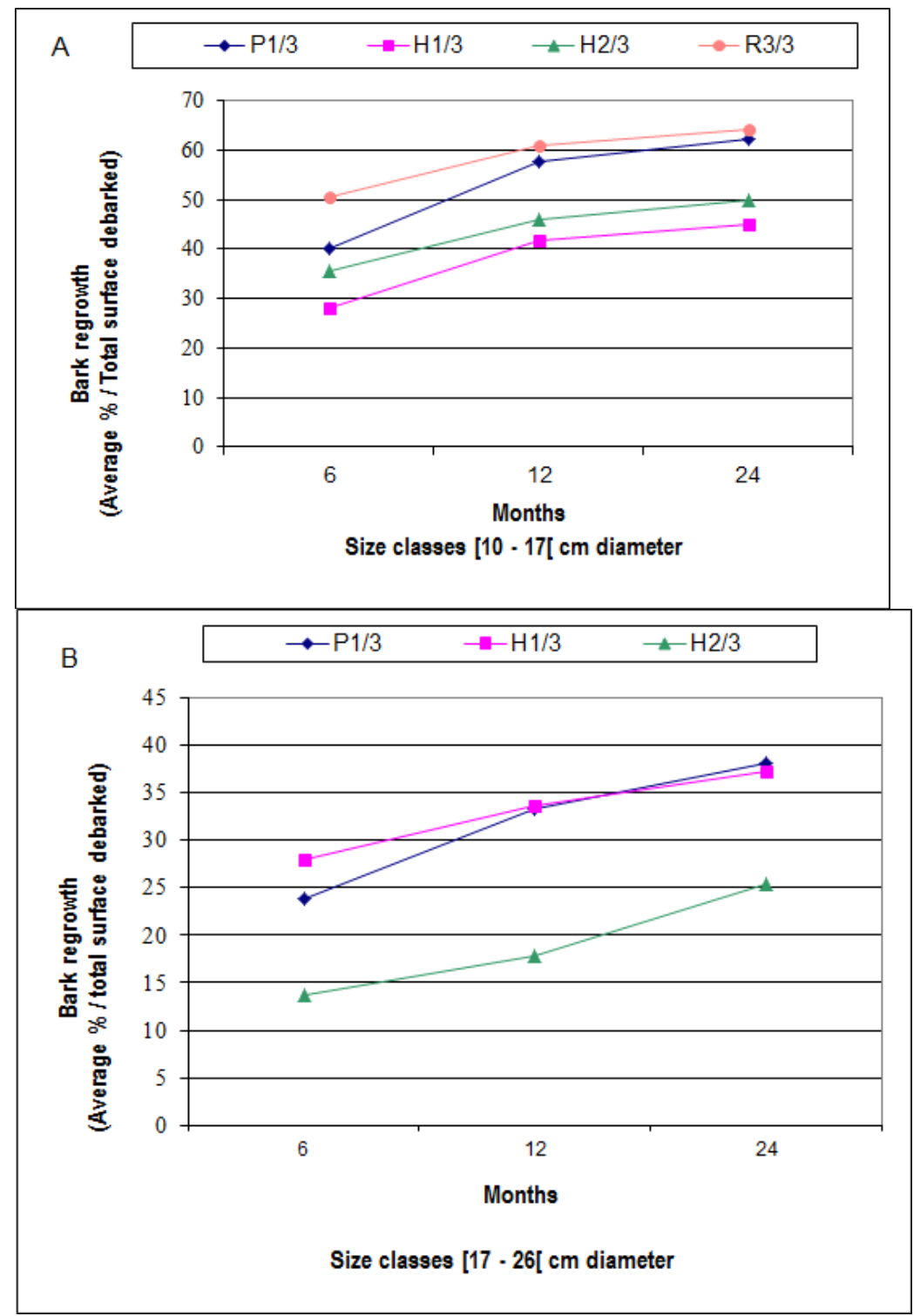

Fig. 7: Characterization of stages of bark regeneration in G. lucida over 2 years following bark harvesting. $A=$ small size classes, $B=$ large size classes; $P 1 / 3=$ Peeling with a machete and debarking over $1 / 3$ of the circumference $(n=16), H 1 / 3=$ Hammering on tree and debarking over $1 / 3$ of the circumference $(n=14), H 2 / 3=$ Hammering on tree and debarking over $2 / 3$ of the circumference $(n=16), R 3 / 3=$ Ring-barking tree by peeling with a machete or hammering on tree $(n=5)$.

A high rate of bark-regrowth was found for trees that bark was hardly removed and narrow strips of bark tissues remained on stem wood, as well as for trees that bark was more or less easily removed (Fig. 8). The differences 
observed in treatments $\mathrm{H} 1 / 3$ for smaller trees and $\mathrm{P} 1 / 3$ for larger trees may be linked to the uneven distribution of trees in forests according to the criteria of bark easiness to be removed as shown in table 2, with higher percentages of trees where bark was more or less easily removed, and a very poor percentage of trees where bark was very easily removed like "cassava peel". In most cases, there were no pests or diseases present on the uncovered part of the wood. Variance analysis (with LSD at $5 \%$ ) of the mean surface area recovered for each treatment shows no significant difference between sizeclasses in overall treatments. However, if the surviving sample ring-barked small trees (due to the number of trees die-back and struck out after illegal stripping) are take into consideration, therefore, there is a significant difference between treatment $\mathrm{R} 3 / 3$ (ring-barked trees) and treatments $P 1 / 3, \mathrm{H} 1 / 3, \mathrm{H} 2 / 3(P<0.001)$.

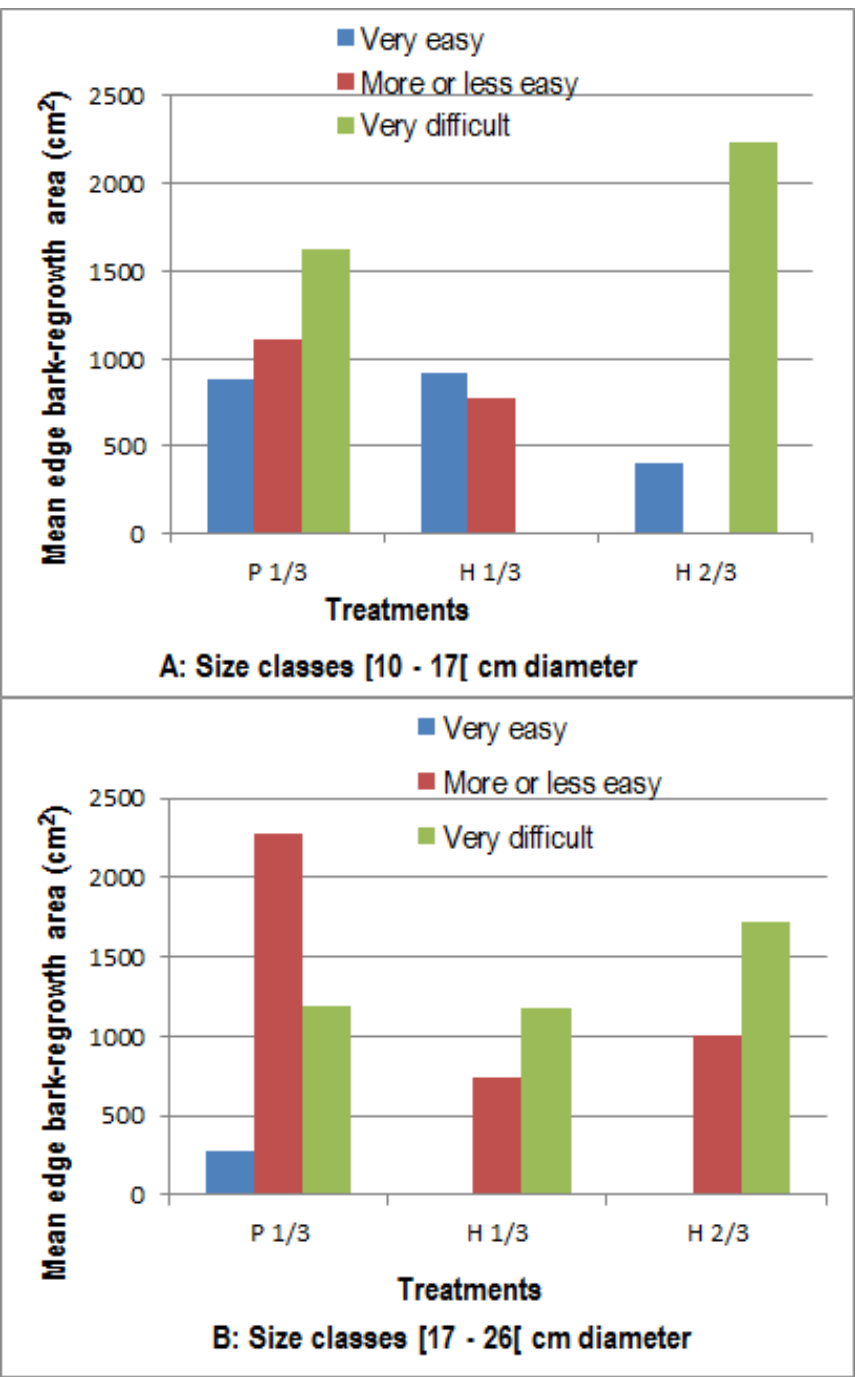

Fig. 8: Influence of bark stripping easiness on rate of edge bark re-growth on Garcinia lucida during 24 months following bark harvesting. $P 1 / 3=$ Peeling with a machete and debarking over $1 / 3$ of the circumference $(n=16), H 1 / 3=$ Hammering on tree and debarking over $1 / 3$ of the circumference $(n=14), H 2 / 3=$ Hammering on tree and debarking over $2 / 3$ of the circumference $(n=$ 16).

\section{DISCUSSION}

During bark harvesting on G. lucida trees, tissues often (almost always) extracted are the outer bark (dead tissues) and the periderm (lives tissues conducting phloem) of the inner bark. Damage to the inner bark interrupts the transport of photosynthates, thereby bereaving roots from nutrients and leading to the 
exhibition of external signs of tree die-back six months later after stripping. Whereas damage to the phellogen reduces the ability of this vascular cambium to produce storage cells and tissues important for stem protection. This explain why damages due to partial peeling of bark with machete (P 1/3) may be superficial and affect only the outer bark and the old phloem and phellem, permitting trees treated by this way to survive ( $0 \%$ mortality) and to further recover from wounds. The results of this study shown that in response to bark removal, G. lucida trees produce stilt-roots, sprouts and bark, indicating a high resilience to bark removal. Re-growth of bark was recorded with all the different debarking treatments, while the $2 / 3$ harvested trees responded by developing new siltroots in addition to bark regrowth. The ability of a species to develop new roots after bark removal is reported for very few species, Delvaux et al. (2009) noticed that only one species (Uapaca togoensis) of 12 species studied produced roots around the wound area, but they did not investigate this phenomenon further. With this study the production of new shoots was observed on trees with bark peeled off over $1 / 3$ of the tree's circumference (P1/3 treatment), and felled trees. According to Geldenhuys et al. (2007), the ability of a species to develop agony shoots around the wound after bark harvesting is related to the ability of that species to produce coppice shoots. Some other species have also been studied for their ability to coppice (Sawadogo et al., 2002; Ky-Dembele et al., 2007) or to re-sprout (Rietkerk et al., 1998; Delvaux et al., 2009). Coppices are a potential source of bark and better knowledge of the complex coppicing response of individual tree species could help in the designing specific strategies for the optimization of coppice management (Kaschula et al., 2005; Neke et al., 2006; Ky-Dembele et al., 2007; Delvaux et al., 2009). According to Cunningham (2014a), whether a tree reproduces from seed or by resprouting from vegetative shoots strongly influences its vulnerability to bark removal or stem cutting. Where stem harvesting occurs, resprounting adds resilience to individual plants and populations, so it is important to consider the use of seeds and sprouts in regeneration of harvested plants. Some trees tend to resprout, some very vigorously, some weakly, and a few not at all. Therefore, intensive harvesting of bark has very different effects on reseeder, or resprouter populations. Growth rates after coppicing are a key factor in determining rotation times if coppice rotations are proposed as a management strategy. The high number of buds and shoots produced by $G$. lucida stumps indicates it's higher resilience and sprouting capacities and the good prospects of a clonal multiplication in domestication strategies (with desirable "genetic" qualities such as bark thickness, organoleptic and chemical components). Bark regrowth patterns varied between harvest treatments with highest values, expressed as percentage to the total number of tree stems exhibiting bark regrowth, recorded in treatments $P$ $1 / 3$ and $H 1 / 3$ (Fig. 4). When expressed as a percentage of re-growth area, higher values were recorded for treatment $P 1 / 3$ (Fig. 7). Bark regrowth from the edges recorded for $\mathrm{G}$. lucida trees was also found for Drimys brasiliensis (Mariot et al., 2014) and Himatanthus drasticus (Baldauf \& dos Santos, 2014). However, over the two-year follow-up period, no tree was able to close the wound completely, suggesting a recovery time of more than two years. Geldenhuys et al. (2007) found that many species showed sheet growth, varying from poor to very good sheet growth. Delvaux et al. (2009) found that only four species, out of the 12 studied, showed a good recovery rate and that only Khaya senegalensis and Lannea kerstingii were able to close the wound completely over the two-year follow-up period. Baldauf \& dos Santos (2014) have indicated that three years were not sufficient for a total recovery of the rhytidome of Himatanthus drasticus. There have been several studies to determine the limits of bark harvesting on species that survived ring barking such as Prunus africana (Cunningham and Mbenkum, 1993) and Mangifera indica (Delvaux, 2009). In other species, ring-barking resulted in the death of all ring-barked trees (Delvaux, 2009). The survival of $G$. lucida ring-barked smaller trees (5 over 10 ), as well as the relative higher percentage of re-growth area recorded for these trees (Fig. 7A) were due or linked to the fact that bark was more or less easily removed on one tree and was very hardly removed on 4 trees. This ability to easily recover bark by ring-barked small trees that bark was hardly stripped, however, does not provide conclusive evidence and is of limited value to evaluate the sustainability of ring-barking practice, as the analysis was based on a limited sample of trees. Furthermore, this practice has been proved by matrix models (Guedje et al., 2007) to induce a sharp drop in the amount of harvestable trees after the first extraction; and populations would not fully recover to the pre-harvest bark availability with this treatment. While in case of populations harvested by partial debarking, the models predicted that the amount of harvestable trees would gradually, decline and reach $50 \%$ of the initial size within the first two decades and that the population would start to recover after 30 years and would be back at initial values after 40 years. A high rate of bark-regrowth was found for trees that bark was hardly removed and narrow strips of bark tissues remained on stem wood, whereas 
little regeneration was observed if the bark was easily removed from wood, thereby living wood without strips of bark tissues. This trend was also found by Delvaux et al. (2009) and Baldaud \& dos Santos (2014). The remained narrow strips of bark, which allowed for sap flow to the roots, may have contributed substantially to tree stability, as well as serving to protect the stem from insect or pathogen attack, and triggered bark regeneration. According to Kengue et al. (1998), bark is easily removed from wood like "cassava peel" when trees are characterized physiologically by the existence or predominance of an upward sap flow, due to good water supply in tree. These authors have highlighted the importance of this tree physiological status and considered it as a determining factor for the success of layering techniques for Dacryodes edulis. G. lucida grows along hilly moist forests versants where water supply is limited for uphill trees, explaining why bark was more or less hardly removed for the majority of trees, probably characterized by the existence of a downward sap flow. Therefore, the physiological status of trees, in term of upward or downward sap flow due to water supply, as it plays an important role in maintaining bark functioning, appears as a decisive factor in plant survival and bark regrowth process; thereby constituting a key element in designing sustainable harvesting practice. Several studies have shown that another important factor for successful recovery of bark was the humidity of the exposed surface immediately after wounding, which may be related to the occurrence of a rainy season (Stobbe et al., 2002; N'Koma Mwange et al., 2003; Juan et al., 2006). As $G$. lucida trees were harvested at the beginning of the rainy season, it is possible that rain has contributed favourably to bark regeneration. Thus, seasonality may be an important variable to be tested in future studies on the bark regeneration potential. However, Mariot et al. (2007) have tested the effect of different harvest seasons on the regenerative ability of Drimys brasiliensis (Winteraceae) in an Atlantic Forest area and found no seasonal differences in the speed of biomass regeneration. As G. lucida is also an Atlantic forest species, it is likely that the remaining narrow bark strips, as well as the yellow and resinous exudates produced along the sides of wounds after bark stripping, may have served to provide the necessary humidity to trigger the cellular division process that had culminated in the recovery of injured xylem and phloem. Romero \& Bolker (2008) have studied the effects of debarking in seven species and found that species that produce some type of exudate showed more efficient bark recovery. Cunningham (2001) also found that plants of certain families, such as Apocynaceae, Euphorbiaceae, Moraceae and Canellaceae, show great resilience after debarking, in part because the cambium was protected by exudates after the bark removal. The yellow exudate that flowed and remained on G. lucida trees after debarking, containing secondary metabolites with antimicrobial properties (Fotié et al., 2007; Gangoué-Pieboji et al., 2007, 2009; Lacmata et al., 2012), may also have served as defensive compounds protecting the stem from insect or pathogen attack, explaining why no pests or diseases were present on the exposed part of the wood. For species with bark exudates, many insects and pathogens appear to be deterred as these defensive substances dry out on the exposed surfaces after damage. However, bark regeneration is a relatively slow process compared to the re-growth of other plant parts such as leaves (Borgtoft-Pedersen, 1996; Gaoue et al., 2013). As highlighted by previous studies (Guariguata \& Gilbert, 1996; Schoonenberg et al., 2003; Romero \& Bolker, 2008; Baldauf \& dos Santos, 2014; Pandey \& Das, 2013), responses to damage of the bark and, consequently, the formulation of criteria for sustainable management, depend on a number of factors, including the type of damaged tissue, the extent of damage, the tree physiology, morphology of the bark, and the presence of exudates. The outermost, conducting phloem tissues are the parts generally harvested, interrupting the translocation of photosynthates and bereaving roots from nutrients. Because of these multiple factors, the effect of bark removal and the sustainability of different harvesting practices are species-specific, as stated by Chungu et al. (2007) and Delvaux et al. (2009). Cunningham \& Mbenkum (1993) indicated that Prunus africana in Cameroon can achieved complete bark re-growth after ring barking. In Nigeria, Fasola \& Egunyomi (2005) indicated that Alstonia boonei, Entandophragma angolense, Khaya grandifolia, Khaya senegalensis and Spondias mombin belong to the fast re-growth group, whereas the bark of Adansonia digitata, Gliricidia sepium , Newbouldia laevis and Theobroma cacao have relatively slow re-growth. In South Africa, Ocotea bullata and Warburgia salutaris show good re-growth; in contrast, the bark of Rapanea melanophloeos shows no re-growth (Geldenhuys et al., 2007). This study indicates that $G$. lucida belongs to the fast re-growth group, according to its abilities to close the wound after partial debarking, it resistance to insect or pathogen attack, and the ability to develop shoots and stilt-roots. These findings constitute biological advantages in designing sustainable harvesting practices and management strategies for $G$. lucida, which is also characterized by effective resilience capacities to 
partial debarking and the possession of important bioactive compounds with great therapeutic potential for new drugs or improved plant medicines. This study has discussed findings on the experimental debarking of $G$. lucida and management implications, which would also apply to other species with the same response to bark stripping as source of raw materials for plant-based drug prospects in developing countries. The following speciesspecific characteristics need to be taken into account to make strip harvesting sustainable:

(i) the bark regeneration capacity (edge growth), which may allow repeated harvest on the same tree;

(ii) the physiological status (downward sap flow) of the tree at the time of harvest, as a key factor ensuring humidity, protection against pathogen attacks, and more moreover, influencing bark's capacity to regenerate after damage. With the good bark regrowth and higher survival rates recorded in $\mathrm{G}$. lucida trees partially stripped ( $\mathrm{P} 1 / 3$, $H 1 / 3$ and $H 2 / 3)$, especially in trees peeled with a machete (P 1/3), these treatments show potential for the implementation of long-term sustainable strip harvesting system and it integration with indigenous resource management. In contrast, ring-barking practice showed high mortality, especially in large trees where most of the trees died, rendering this practice unsuitable for bark stripping as a method of long-term bark harvesting. Nevertheless, there are also major limitations in using regenerated bark, as the time required to re-attain preharvest bark thickness and fibre quality, as well as the chemical composition for $G$. lucida as well as for many other species, are still unknown. Bark differs from all other plant parts in development and anatomy, as well as chemical composition (Pandey et al., 2011; Costa et al., 2014; Romero, 2014; Eich et al., 2015). Chemical compounds found dispersed in low concentrations throughout most of the plant are highly concentrated in bark than in other plant tissues (Young, 1971; Romero, 2014). Although inner bark and wood are derived from vascular cambium, they are fundamentally different in structure and function, but are more similar in chemical constituents than either is to outer bark. Unfortunately,

\section{ACKNOWLEDGEMENTS}

This work received financial support from the Ministry of Higher Education in Cameroon. We are grateful to the inhabitants of Nyangong village for their hospitality and

\section{REFERENCES}

Baldauf C and dos Santos FAM, 2014. The effect of management systems and ecosystem types on with the study of bark chemistry, the bark tissues from which compounds were derived are rarely specified. In addition, the chemical composition of bark tissues varies as a function of ontogeny, history of disturbance, environmental conditions and even the height on the tree at which a sample is taken (Romero, 2014). Furthermore, in some conifers, chemical composition varies with stress level and other factors, and there can be chemical differences in the resin produced before and after wounding (Klepzip et al., 1996). To protect themselves from beetle larvae and their associated pathogenic fungi, some trees develop traumatic resin ducts and produce resin with a chemical composition different from that in resins produced before wounding, with more phenolic compounds in traumatic canals and in reaction tissue (Berg et al., 2013; Romero, 2014). Similarly, in response to bark removal $G$. lucida trees may also produce exudate and young bark tissues with a chemical composition different from that produced before wounding. Stressreleasing mechanisms remain to be tested and little formal studies are known on the long-term effects of frequent bark removal on regenerated bark chemical composition. Therefore, extensive research on rates of bark regeneration in relation to bark structure, physiology and chemical composition would further assist the implementation of sustainable strip to source raw bark materials for plant-based drug development. Shoot growth and stilt-root development in G. lucida species allows for other management options than strip harvesting, including coppice shoots management rotations and domestication. These alternative management options could easily be integrated into forest management planning and regulations as proposed by Guedje et al. (2010) or might be considered as a byproduct of timber harvesting and could be integrated to the SCH (Senility Criteria Harvesting) timber yield regulation system, as practiced in the Southern Cape forests, basing on harvesting of dying trees equivalent to the natural mortality rates (Seydack et al., 1995; Ngubeni, 2015).

participation during fieldwork. We also thank the anonymous reviewers for their precious comments.

bark regeneration in Himatanthus drasticus (Apocynaceae): recommendations for 
sustainable harvesting. Environmental Monitoring and Assessment 186: 349-359.

Berg AR, Heald CL, Huff Hartz KE, Hallar AG, Meddens AJH, Hicke JA, Lamarque JF, Tilmes S, 2013. The impact of bark beetle infestations on monoterpene emissions and secondary organic aerosol formation in western North America. Atmospheric Chemistry and Physics 13(6): 3149-3161.

Bodeker G, van Klooster C, Weisbord E, 2014. Prunus africana (Hook.f.) Kalkman: The overexploitation of a medicinal plant species and its legal context. Journal of Alternative and Complementary Medicine 20(11): 810-822.

Borgtoft-Pedersen $\mathrm{H}$, 1996. Production and harvest of fibres from Aphandra natalia (Palmae) in Ecuador. Forest Ecology and Management 80: 155-161.

Camefort $H, 1977$. Morphologie des végétaux vasculaires : cytologie, anatomie, adaptations, $2^{\text {nd }}$ Edition, Doin Editeurs, Paris, France. 432 pp.

Chikamai B, Tchatat M, Tieguhong JC, Ndoye O, 2009. Forest management for non-wood forest products and services in Sub-Saharan Africa. Discovery and Innovation 21(1): 50 - 59.

Chungu D, Muimba-Kankolongo A, Roux J, Malambo F, 2007. Bark removal for medicinal use predisposes indigenous forest trees to wood degradation in Zambia. Southern Hemisphere Forestry Journal 69(3): 157-163.

Costa A, Nunes LC, Spiecker H, Graça J, 2015. Insights into the responsiveness of Cork Oak (Quercus suber L.) to bark harvesting. Economic Botany 69(2): 171-184.

Costa CAE, Pinto PCR, Rodrigues AE, 2014. Evaluation of chemical processing impact on $E$. globulus wood lignin and comparison with bark lignin. Industrial Crops and Products 61: 479-491.

Cunningham AB, 2001. Applied ethnobotany: people, wild plant use and conservation. Earthscan, London, United Kingdom.

Cunningham $A B, 2014 a$. The Ethnobotany, use, and sustainable harvest of bark: a review. Cunningham $A B$, Campbell BM, Luckert MK (Editors), Advances in Economic Botany, Volume 17, The New York Botanical Garden Press, Bronx, New York, USA. pp. 27-55.

Cunningham AB, 2014b. A global footprint on Africa and Madagascar: a review of international trade in Prunus Africana (Rosaceae) bark. Cunningham $A B$, Campbell BM, Luckert MK (Editors),
Advances in Economic Botany, Volume 17, The New York Botanical Garden Press, Bronx, New York, USA. pp. 153-177.

Cunningham AB and Mbenkum FT, 1993. Sustainability of harvesting Prunus africana bark in Cameroon: a medicinal plant in international trade. People and Plants Working Paper no 2, Division of Ecological Sciences, UNESCO, Paris, France.

Delvaux C, Sinsin B, Darchambeau F, Van Damme P, 2009. Recovery from bark harvesting of 12 medicinal tree species in Benin, West Africa. Journal of Applied Ecology 46(3): 703-712.

Djaligue Y, 2007. Déforestation : menace sur l'«Essok» Dossier. Bubinga 122: 5-7.

Eich S, Volk TA, Eisenbies MH, 2015. Bark content of two shrub Willow cultivars grown at two sites and relationships with centroid bark content and stem diameter. BioEnergy Research 8(4): 16611670.

Fasola TR and Egunyomi A, 2005. Nigerian usage of bark in phytomedecine. Ethnobotany Research and Applications 3: 73-77.

Fotie J, Bohle DS, Olivier M, Gomez MA, Nzimiro S, 2007. Trypanocidal and antileishmanial dihydrochelerythrine derivatives from Garcinia lucida. Journal of Natural Products 70(10): 1650-1653.

Gangoué-Piéboji J, Baurin S, Frère JM, Ngassam $P$, Ngameni B, Azebaze A, Pegnyemb DE, Watchueng J, Goffin C, Galleni M, 2007. Screening of some medicinal plants from Cameroon for $\beta$-Lactamase inhibitory activity. Phytotherapy Research 21: 284287.

Gangoué-Pieboji J, Eze N, Djintchui AN, Ngameni B, Tsabang N, Pegnyemb DE, Biyiti L, Ngassam P, Koulla-Shiro S, Galleni M, 2009. The in-vitro antimicrobial activity of some medicinal plants against $\beta$-lactam-resistant bacteria. The Journal of Infection in Developing Countries 3(9): 671680.

Gaoue OG, Horvitz CC, Ticktin T, Steiner UK, Tuljapurkar S, 2013. Defoliation and bark harvesting affect life-history traits of a tropical tree. Journal of Ecology 101(6): 1563-1571.

Geldenhuys CJ, Syampungani S, Meke GS, Vermeulen WJ, 2007. Response of different species to bark harvesting for traditional medicine in Southern Africa. Multiple Use Management of Natural Forests and Woodlands: Policy Refinement and Scientific Progress. Bester JJ, Seydack AHW, Vorster T, Van der Merwe IJ, Dzivhani S 
(Editors), Department of Water Affairs and Forestry, Pretoria, South Africa. pp. 55-62.

Guariguata MR and Gilbert GS, 1996. Interspecific variation in rates of trunk wound closure in a Panamanian lowland forest. Biotropica 28(1): 23-29.

Guedje NM, 2014. Harvest of bark from Garcinia lucida (Clusiaceae) in South Cameroon. Cunningham AB, Campbell BM, Luckert MK (Editors), Advances in Economic Botany, Volume 17, The New York Botanical Garden Press, Bronx, New York, USA. pp.137-149.

Guedje NM, Zuidema PA, During H, Foahom B, Lejoly J, 2007. Tree bark as a non-timber forest product: The effect of bark collection on population structure and dynamics of Garcinia lucida Vesque. Forest Ecology and Management 240: $1-12$.

Guedje NM, Fokunang CN, Jiofack TRB, Dongmo FR, 2010. Opportunités d'une exploitation soutenue des plantes médicinales dans l'aménagement forestier. International Journal of Biological and Chemical Sciences 4 (4) : 1346-1372.

Juan D, Hong-Li X, De-Qiang Z, Xin-Qiang H, Min-Jie W, Ying-Zhang L, Ke-Ming C, Meng-Zhu L, 2006. Regeneration of the secondary vascular system in poplar as a novel system to investigate gene expression by a proteomic approach. Proteomics 6(3): 881-895.

Kamanyi A, Bopelet A, Sondengam BL, Kimbu FS, 1990. Preliminary phytochemical and pharmacological studies of the seeds of Garcinia lucida (Vesque). Nigerian Journal of Physiological Sciences 6(1): 62-66.

Kaschula SA, Twine WE, Scholes MC, 2005. Coppice harvesting of fuelwood species on a South African common: utilizing scientific and indigenous knowledge in community based natural resource management. Human Ecology $33: 387-418$.

Kengue J, Tchio F, Ducelier D, 1998. Le marcottage aerien: une technique pour la multiplication végétative du safoutier. Actes du 2 ème séminaire international sur la valorisation du safoutier et autres oléagineux non conventionnels. Kapseu $C$ and Kayem GJ (Editors), ENSAI, Presses Universitaires de Yaoundé, Yaoundé, Cameroun. pp 123-135.

Klepzig KD, Smalley EB, Raffa KF, 1996. Combined chemical defenses against an insect-fungal complex. Journal of Chemistry and Ecology 22:1367-1388.

Kunle OF, Egharevba HO, Ahmadu PO, 2012. Standardization of herbal medicines-A review. International Journal of Biodiversity and Conservation 4(3): 101-112.

Ky-Dembele C, Tigabu M, Bayala J, Ouedraogo SJ, Oden PC, 2007. The relative importance of different regeneration mechanisms in a selectively cut savanna-woodland in Burkina Faso, West Africa. Forest Ecology and Management 243: 28-38.

Lacmata ST, Kuete V, Dzoyem JP, Tankeo SB, Teke GN, Kuiate JR, Pages JM, 2012. Antibacterial activities of selected Cameroonian plants and their synergistic effects with antibiotics against bacteria expressing MDR phenotypes. Evidence-Based Complementary and Alternative Medicine 2012: 1-11. Article ID 623723, 11 pp.

Mariot A, Mantovani A, dos Reis MS, 2007. Developing a basis for management of natural populations of Drimys brasiliensis in Brazil, used for its bark. Multiple Use Management of Natural Forests and Woodlands: Policy Refinement and Scientific Progress. Bester JJ, Seydack AHW, Vorster T., Van der Merwe IJ, Dzivhani S (Editors), Department of Water Affairs and Forestry, Pretoria, South Africa. pp. 76-81.

Mariot A, Mantovani A, Reis MS, 2014. Bark Harvesting Systems of Drimys brasiliensis Miers in the Brazilian Atlantic Rainforest. Anais da Academia Brasileira de Ciências 86(3): 1315-1326.

Momo IJ, Kuete V, Dufat H, Michel S, Wandji J, 2011. Antimicrobial activity of the methanolic extract and compounds from the stem bark of Garcinia lucida Vesque (Clusiaceae). International Journal of Pharmacy and Pharmaceutical Sciences 3: 215-217.

Ndoye O, Ruiz-Perez M, Mamoun AD, Lema-Ngono D, 2000. Les effets de la crise économique et de la dévaluation sur l'utilisation des plantes médicinales au Cameroun. Implications pour la gestion durable des forêts. La gestion des forêts denses africaines aujourd'hui. Nasi R, Amsallem I, Drouineau S (Editors), CDRom, Cirad, Montpellier, France. pp. 76-81.

Ndoye O, Ruiz-Perez M, Eyebe A, 2001. NTFP markets and potential degradation of forest resources in Cameroon: the case of Garcinia lucida. European Tropical Forest Research Network News 32: 44-45. 
Neke KS, Owen-Smith N, Witkowski TF, 2006. Comparative resprouting response of Savanna woody plant species following harvesting: the value of persistence. Forest Ecology and Management 232: 114-123.

Ngubeni, N. 2015. Bark re-growth and wood decay in response to bark stripping for medicinal use, MSc thesis, Faculty of AgriScience, Stellenbosch University, Stellenbosch. 112 pp.

N'koma-Mwange K, Hou HW, Cui KW, 2003. Relationship between endogenous indole-3acetic acid and abscisic acid changes and bark recovery in Eucommia ulmoides Oliv. after girdling. Journal of Experimental Botany 54: 1899-1907.

Nyemba AM, Ngando-Mpondo T, Connolly JD, Rycroft DS, 1990. Cycloartane derivatives from Garcinia lucida. Phytochemistry 29(3): 994-997.

Pandey AK, 2015. Sustainable bark harvesting of important medicinal tree species, India. Ecological sustainability for non-timber forest products - dynamics and case studies of harvesting. Shackleton CM, Pandey AK, Ticktin T (Editors), Routledge, Park Square, Milton Park, Abingdon, Oxon and New York, USA. pp. 163-178.

Pandey AK and Das R, 2013. Good Field Collection Practices and Quality Evaluation of Medicinal Plants: Prospective Approach to Augment Utilization and Economic Benefits. Research Journal of Medicinal Plant 8(1): 1-19.

Pandey AK, Yadav S, Sahu SK, 2011. Sustainable bark harvesting and phytochemical evaluation of alternative plant parts in Holarrhena antidysenterica R. Br. Sans (Kutaj). International Journal of Green Pharmacy 5(2): 107-112.

Rietkerk M, Blijdorp R, Slingerland M, 1998. Cutting and resprouting of Detarium microcarpum and herbaceous forage availability in a semiarid environment in Burkina Faso. Agroforestry Systems 41: 201-221.

Romero C, 2014. Bark: structure and functional ecology. Cunningham AB, Campbell BM, Luckert MK (Editors), Advances in Economic Botany, Volume 17, The New York Botanical Garden Press, Bronx, New York, USA. pp. 5-25.

Romero C and Bolker BM, 2008. Effects of stem anatomical and structural traits on responses to stem damage: an experimental study in the Bolivian Amazon. Canadian Journal of Forest Research 38(3): 611-618.
Romero C, Dovie DBK, Gambiza J, Luoga E, Schmitt S, Grundy I, 2014. Effets of commercial bark harvesting on Adansonia digitata (Baobab) in the Save-Ozi Valley, Zimbabwe, with considerations for its management. Cunningham $A B$, Campbell BM, Luckert MK (Editors), Advances in Economic Botany, Volume 17, The New York Botanical Garden Press, Bronx, New York, USA. pp. 95-114.

Sawadogo L, Nygard R, Pallo F, 2002. Effects of livestock and prescribed fire on coppice growth after selective cutting of Sudanian savannah in Burkina Faso. Annals of Forest Science 59: 185-195.

Schoonenberg T, Pinard M, Woodward S, 2003. Responses to mechanical wounding and fire in tree species characteristic of seasonally dry tropical forest of Bolivia. Canadian Journal of Forest Research 33(2): 330-338.

Senkoro AM, Barbosa FM, Moiane SF, Albano G, de Barros AIR, 2014. Bark Stripping from forest tree species in Madjadjane, Southern Mozambique: medicinal uses and implications for conservation. Natural Resources 5: 192-199.

Seydack, AHW, Vermeulen WJ, Heinz HE, Durrheim GP, Vermeulen C, Willems, D, Ferguson MA, Huisamen J, Roth J, 1995. An unconventional approach to timber yield for multi-aged, multispecies forests. II. Application to a South African forest. Forest Ecology and Management 77: 155-168.

Tshisikhawe MP, van Rooyen MW, Bhat RB, 2012. An evaluation of the extent and threat of bark harvesting of medicinal plant species in the Venda Region, Limpopo Province, South Africa. International Journal of Experimental Botany 81: 89-100.

Stobbe H, Schmitt U, Eckstein D, Dujesiefken D, 2002. Developmental stages and fine structure of surface callus formed after debarking of living lime trees (Tilia sp.). Annals of Botany 89: 773782.

van Andel TR, Croft S, van Loon EE, Quiroz D, Towns AM, Raes N, 2015. Prioritizing West African medicinal plants for conservation and sustainable extraction studies based on market surveys and species distribution models. Biological Conservation 181: 173-181.

van Damme P and Delvaux C, 2012. Sustainable harvest methods for medicinal bark from trees (a Research and Development case study from 
Benin). Bulletin des Séances de l'Académie Royale des Sciences D'Outre-Mer 58(2-4) : 377398.

van Dijk JFW, 1999. Non-timber forest products in the Bipindi-Akom II Region, Cameroon: a Socioeconomic and Ecological Assessment. Tropenbos-Cameroon Series 1, The Tropenbos Cameroon Programme. Kribi, Cameroon.

Vermeulen WJ, Geldenhuys CJ, Esler KJ, 2012. Response of Ocotea bullata, Curtisia dentata and Rapanea melanophloeos to medicinal bark stripping in the Southern Cape, South Africa: implications for sustainable use. Southern Forests 74 (3): 183-193.

World Health Organization (WHO), 2004. WHO Guidelines for Good Manufacturing and Collection Practices (GACP) for medicinal plants.

http://www.who.int/medicines/library/trm/medicin alplants/agricultural.pdf

Young HE, 1971. Preliminary estimates of bark percentages and chemical elements in complete trees of eight species in Maine. Forest Production Journal 21: 56-59. 